\title{
Virgin Olive Oil Quality Is Affected by the Microbiota that Comprise the Biotic Fraction of the Oil
}

\author{
Biagi Angelo Zullo * and Gino Ciafardini \\ Department of Agricultural, Environmental and Food Sciences, University of Molise, Via De Sanctis, \\ I-86100 Campobasso, Italy; ciafardi@unimol.it \\ * Correspondence: biagi.zullo@unimol.it; Tel.: +39-0874-404689
}

Received: 2 April 2020; Accepted: 27 April 2020; Published: 1 May 2020

\begin{abstract}
This review summarizes the current knowledge on the effects of oil-borne yeasts on the physicochemical, sensorial, and health-related characteristics of virgin olive oil (VOO) during storage. Bacteria, yeasts, and molds constitute the biotic fraction of freshly produced VOO. During storage, the bacteria and molds often die after a short period, while the yeasts survive and condition the quality of VOO. To date, approximately twenty-four yeast species have been isolated from different types of olive oil and its by-products, and seven of these species have been identified as new species. The activity of some yeasts of the biotic fraction of olive oil improves the sensorial characteristics of VOO. Some yeasts can also worsen the quality of the product by allowing the appearance of defects, oxidation of polar phenols, and triacylglycerol hydrolysis. Some yeast species of VOO show in vitro beneficial health effects, such as probiotic and antioxidant activities.
\end{abstract}

Keywords: virgin olive oil (VOO); biotic fraction; yeast species; virgin olive oil quality; technological and health properties

\section{Introduction}

Virgin olive oil (VOO) is a product obtained by mechanical extraction from the olive fruit and can be consumed without further refining. It is the most important vegetable oil used for human nutrition in the Mediterranean area. It is known worldwide for health benefits, which are attributed to its antioxidant component and high content of unsaturated fatty acids [1,2]. Freshly produced VOO appears cloudy due to the presence of micro-drops of oil-mill wastewater and numerous solid particles of olive skin and pulp covered by water films, representing the suspended fraction of VOO [3,4]. During storage, the suspended material settles at the bottom of the container to form a sediment. To reduce the suspended material in oil, freshly produced VOO is filtered through cotton filters under pressure in the bottling industry. However, filtration of the newly produced VOO has not been completely accepted, because some studies have shown that filtration reduces the oil stability and the concentration of phenolic compounds during storage $[5,6]$. On the contrary, other authors have reported that elimination of the sediment improves the shelf life of $\mathrm{VOO}$ and prevents the development of an off flavor during storage $[7,8]$. The chemical composition of VOO is represented by major compounds $(98 \%$ of the total oil weight) and minor compounds (about $2 \%$ ), including more than 230 chemical compounds, such as aliphatic and triterpenic alcohols, sterols, hydrocarbons, volatile compounds, and antioxidants. The major antioxidants of VOO include carotenes and bioactive phenolic compounds (apolar and polar phenols). Apolar phenols such as tocopherols are also found in other vegetable oils, while the polar phenolic component is typical of VOO [9]. The polar phenolic compounds of VOO include phenolic acids and derivatives, phenolic alcohols, secoiridoids, lignans, and flavonoids, which exhibit antioxidant, anti-inflammatory, anticancer, antimicrobial, and antiviral activities [10-16]. Since VOO is produced over a short period of time, it must be stored for the rest of the year until the next olive oil 
campaign. During storage, VOO is subject to hydrolysis, oxidation, autoxidation, and polymerization, leading to the deterioration of its components, quality and nutritional values, alteration of its oxidative stability, and reduction in its health benefits $[17,18]$. In a previous investigation, Ciafardini and Zullo [19] demonstrated, for the first time, the presence of a biotic fraction, consisting of the microbiota, in the oily mass of the newly produced olive oil. The microbiota of VOO includes yeasts, bacteria, and molds. Several studies conducted on the VOO microbiota showed that the yeasts were capable of conditioning the physicochemical, sensorial, and health-related characteristics of VOO during storage [20-24]. In this study, the effects of the biotic fraction of VOO on product quality during its storage have been reviewed, and the possible biotechnological exploitation of the health benefits of some oil-borne yeasts has been discussed.

\section{The Microbiota of VOO}

The oily fraction of healthy olive fruits is free of microorganisms before harvest. However, during the extraction phase in the mill, the oily fraction is colonized by microorganisms from various sources, including the carposphere of the olives $[25,26]$. The bacteria and molds present in the oily mass of the newly produced $\mathrm{VOO}$ often die after a short time, while the yeasts survive and constitute the microbiota of freshly produced VOO [25-27].

\subsection{Yeast Survival and Distribution}

The concentration of yeasts detected in VOO depends on several factors, such as filtration, sedimentation, and the physicochemical composition. Filtration reduces the initial microbial concentration of VOO, which, in some cases, can be partially or completely restored by cell replication during storage. Although filtered oils contain fewer yeast species, some of them demonstrate the maximum colony forming units (CFUs) number of yeasts, ranging from 3.50 logs to 4.20 logs per $\mathrm{mL}[28,29]$. Similarly, in unfiltered olive oils, the maximum CFUs number of yeasts ranged from 4.56 logs per $\mathrm{mL}$ in the newly produced olive oils and 3.03 logs per $\mathrm{mL}$ after one year of storage [30]. The survival of yeasts in the oily mass is conditioned by the water content and chemical composition of VOO $[29,31,32]$. The water content in VOOs varies from $0.15 \%(w / w)$ to over $0.36 \%$ $(w / w)$, depending on the use of the oil extraction system and product filtration. However, water content above $0.25 \%(\mathrm{w} / \mathrm{w})$ is considered high, because this not only promotes the growth of microorganisms, but also activates enzymes that are harmful to oil quality [33]. Depending on the concentration of the total polar phenolic compounds in VOO during storage, the physiological activity of yeasts is modified, exerting a strong selective pressure on the survival of yeast species. A study was performed with the Yamadazyma terventina 2092 dimorphic yeast strain, which was inoculated into VOO with a low or high phenolic compound content. Dimorphic yeasts demonstrate an equilibrium between spherical and polarized growth (pseudohyphal tip elongation), and this can be triggered while transitioning from favorable to unfavorable environmental conditions. In the previous study, the $Y$. terventina 2092 yeast strain was inoculated into VOO with different phenolic compound concentrations (100 mg and $350 \mathrm{mg}$ caffeic acid equivalent (CAE) per $\mathrm{kg}$ ) and stored at $15^{\circ} \mathrm{C}$ for three months. Corn Meal Agar medium (CMA, Oxoid code CM 0103) was used for pseudohyphae production of Yamadazyma terventina 2092 dimorphic yeast strain. The yeast cells were extracted from the oil samples at the end of the incubation period and analyzed with a scanning electron microscope (SEM) according to Zullo et al. [29] The $Y$. terventina 2092 dimorphic yeast strain showed polarized growth only in the sample of VOO with a high total polar phenolic content equal to $350 \mathrm{mg}$ CAE per kg (Figure 1). 

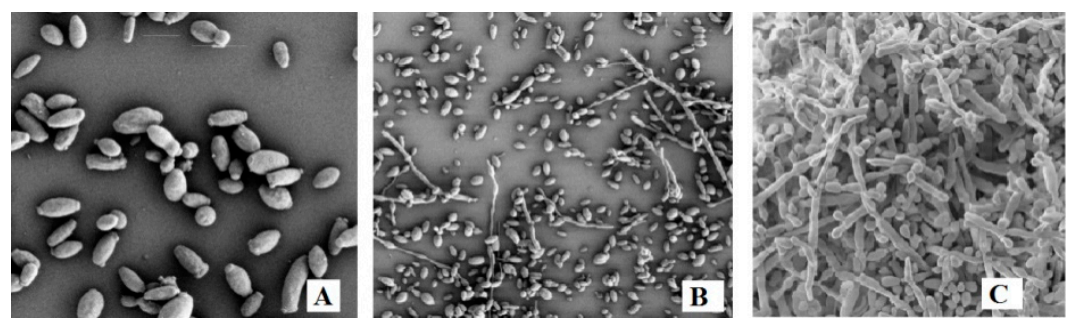

Figure 1. SEM observation of the Yamadazyma terventina 2092 yeast strain after three months of incubation in virgin olive oil (VOO) with low (A) and high (B) total polar phenolic content; (C) Yeast growth in the CMA medium.

In a previous research study, it was observed that a high phenolic content shortens the survival period in olive oil of some opportunistic pathogenic yeasts, including Candida parapsilosis [31]. The fatty acids and triglycerides present in VOO also inhibit the growth of yeasts. Several yeast species, such as Meyerozyma guilliermondii, C. parapsilosis, and Candida diddensiae, have been reported to exhibit concentration-dependent sensitivity to linoleic acid [29]. The survival of yeasts during oil storage is also affected by the blending of monovarietal VOOs. A recent study conducted by Zullo and Ciafardini [34] has shown that the number of yeasts markedly decreased in blended VOO during the storage compared to the starting monovarietal VOOs. In the oleic habitat, basidiomycetous yeasts (Cryptococcus, Rhodotorula, and Sporobolus) were found on the leaves and on the fruits and not in the freshly produced VOO [35]. Oil-borne yeasts have been isolated from oils extracted from different varieties of olives, using the method described by Zullo and Ciafardini [29]. In detail, $10 \mathrm{~mL}$ of the oil samples were micro-filtered through sterile nitrocellulose filters, with a porosity of $0.45 \mu \mathrm{m}$. The nitrocellulose filter of the sample was homogenized with a Turrax homogenizer (IKA, Milan, Italy), in the presence of sterile physiological solution. Then, the initial volume equal to $10 \mathrm{~mL}$ was reconstituted and the microbial suspension was used for 10-fold serial dilutions, with a sterile physiological solution of $0.9 \%(\mathrm{w} / \mathrm{v}) \mathrm{NaCl}$. Yeasts were detected using Petri dishes with MYGP agar medium, as described by Ciafardini and Zullo [21]. Several yeast species were isolated from different types of olive oils, and seven of these were new species (Table 1). Yeasts belonging to $C$. diddensiae and Nakazawaea wickerhamii have been found in commercial VOO, available in supermarkets, and olive oil produced from the Moraiolo and Frantoio varieties [23,28]. Yeast species such as Candida norvegica, Candida oleophila, Debariomyces hansenii, C. diddensiae, and Wicherhamomyces anomalus were found in the newly produced Taggiasca olive oil, while only $W$. anomalus survived in the same oil after six months of storage [26]. Other species including Groenewaldozyma aurigiensis, and Lachancea fermentati were isolated from olive oil produced in Spain [36], while the yeast Kuraishia capsulata was isolated by us for the first time in a blended VOO, prepared from an oil of an Italian origin and one from Portugal. K. capsulata is often recovered from frass or tunnels of larvae underneath the bark of certain conifers. This yeast species produces extracellular polysaccharides, allowing the cells to adhere to the bark beetles, and this adhesive property probably aids in dispersal [37]. A low cell count of opportunistic pathogenic yeast species, such as C. parapsilosis and M. guilliermondii, isolated from commercial olive oil, was observed [29]. In the sediments of VOO and spoiled olive oil, unknown yeast species including Brettanomyces acidodurans, Candida adriatica, Kuraishia mediterranea, Nakazawaea molendinolei, Ogateae histrianica, Ogateae kolombanensis, and Y. terventina were recently isolated and classified as new species [36,38-41]. C. adriatica, N. molendinolei, and Y. terventina are yeast species that are frequently isolated from Italian oils produced in central and northern Italy. Other species, such as K. mediterranea, O. histrianica, and O. kolombanensis, are methylotrophic yeast species that are frequently isolated from olive oil sediments. These yeast species can assimilate methanol, produced as a by-product of pectin metabolism, because they are pectinolytic [39,41]. Pectinolytic yeasts use polygalacturonase to utilize pectin for growth and have been previously identified as the causative agents of spoilage defects in table olives [42,43]. Similarly, the new yeast $B$. acidodurans produces acetic 
acid in olive oil sediments, resulting in a wine-vinegary defect in the product [36]. Other yeast species, including Saccharomyces cerevisiae, Yamadazyma mexicana, Yamadazyma nakazawaea, and Candida spp. (three species), were isolated from Sardinian olive oils. C. adriatica was the only yeast species identified in VOO obtained from olives of the Semidana variety. From VOO of the Nera di Gonnos variety, three yeast species, namely S. cerevisiae, Candida temnochilae, and $Y$. nakazawaea, were obtained, while from VOO of the Nocellara del Belice variety, two yeast species, Y. mexicana and Candida dendronema, were obtained [44].

Table 1. Yeast species isolated from olive oil identified through D1/D2 (26S) rDNA sequencing.

\begin{tabular}{|c|c|c|c|}
\hline Yeast Species & Substrate & Location & Reference \\
\hline Brettanomyces acidodurans & olive oil & Spain & [36] \\
\hline (New species) & spoiled olive oil & Israel & [36] \\
\hline Brettanomyces californica & virgin olive oil & Italy & [22] \\
\hline & olive oil sediment & Slovenia & [38] \\
\hline \multirow[t]{3}{*}{ (New species) } & virgin olive oil & Italy & [38] \\
\hline & spoiled olive oil & Croatia & [38] \\
\hline & oil from decanter & Italy & [23] \\
\hline Candida dendronema & olive oil & Italy & [44] \\
\hline Candida diddensiae & virgin olive oil & Italy & [29] \\
\hline Candida norvegica & virgin olive oil & Italy & [26] \\
\hline Candida oleophila & virgin olive oil & Italy & [26] \\
\hline Candida parapsilosis & virgin olive oil & Italy & [28] \\
\hline Candida temnochilae & olive oil & Italy & [44] \\
\hline Debaryomyces hansenii & virgin olive oil & Italy & [26] \\
\hline Groenewaldozyma auringiensis & olive oil & Spain & [36] \\
\hline Lachancea fermentati & olive oil & Spain & [36] \\
\hline Kuraishia capsulata & virgin olive oil & Italy & [Date unpublished] \\
\hline Kuraishia mediterranea & olive oil sediment & Slovenia & {$[41]$} \\
\hline \multirow[t]{2}{*}{ (New species) } & spoiled olive oil & Portugal & {$[41]$} \\
\hline & virgin olive oil & Italy & [Date unpublished] \\
\hline Meyerozyma guilliermondii & virgin olive oil & Italy & {$[29]$} \\
\hline Nakazawaea molendinolei & virgin olive oil & Italy & [38] \\
\hline \multirow[t]{4}{*}{ (New species) } & virgin olive oil & Croatia & [38] \\
\hline & virgin olive oil & Slovenia & [38] \\
\hline & spoiled olive oil & Israel & [38] \\
\hline & oil from decanter & Italy & [23] \\
\hline Nakazawaea wickerhamii & virgin olive oil & Italy & [28] \\
\hline (Candida wickerhamii) & oil from decanter & Italy & [23] \\
\hline Ogataea histrianica & olive oil sediment & Slovenia, Italy & [39] \\
\hline (New species) & virgin olive oil & Italy & [22] \\
\hline Ogateae kolombanensis & olive oil sediment & Slovenia & [39] \\
\hline (New species) & virgin olive oil & Italy & [Date unpublished] \\
\hline Yamadazyma mexicana & olive oil & Italy & {$[44]$} \\
\hline Yamadazyma nakazawaea & olive oil & Italy & [44] \\
\hline Saccharomyces cerevisiae & olive oil & Italy & [44] \\
\hline Wickerhamomyces anomalus & virgin olive oil & Italy & [26] \\
\hline Yamadazyma terventina & virgin olive oil & Italy & [40] \\
\hline (New species) & oil from decanter & Italy & [23] \\
\hline
\end{tabular}

\subsection{Bacteria and Molds}

Bacterial species, such as Stenotrophomonas rhizophila, Pseudomonas cedrina, Pseudomonas stutzeri, and Pantoea septica, were found in the one-year stored olive oils obtained from blends of five different olive cultivars, including Leccino, Coratina, Ogliarola, Frantoio, and Cellina di Nardò varieties. Two bacterial strains of the species P. septica produce carotenoids and bioemulsifiers, enabling the bacteria to survive and grow an unfavorable substrate [45]. Other bacteria, belonging to Bacillus spp., Brevibacillus spp., Micrococcus spp., Staphylococcus spp., Kocuria spp., Lysinbacillus spp., and Lactobacillus spp., were found 
in VOOs, which were subject to enrichment and obtained from different Italian varieties [46]. A study conducted by Zullo et al. [27] showed that coliform bacteria could survive and reproduce in VOO containing low levels of total polar phenols. The laboratory inoculation trials demonstrated that when the bacterium Escherichia coli, isolated from the carposheres of olives, was transferred to olive oil containing high polar phenol content, its growth was completely inhibited after 15 days of storage. On the contrary, the bacterium reproduced quickly when it was inoculated in VOO containing a lower concentration of polar phenols. To date, a few studies on the presence of bacteria in VOO have focused on biodiversity and their potential biotechnological utility. However, there is a lack of studies on the influence of bacteria on the VOO quality during storage. The mold content in VOO obtained from healthy olives was reported to be low because the mold died during storage [30]. Molds, from different VOO samples, mainly belonged to the genus Aspergillus [47].

\section{Influence of Yeasts on VOO Quality}

Based on enzymatic activities, microorganisms of the olive carphosheres can influence the oil quality during the extraction process in the mill. In a study by Vichi et al. [48], it was reported that the oils obtained from microbiologically-contaminated olives were of poor quality and the effect of the microbiota on oil characteristics was greater than that exerted by malaxation conditions, such as time and temperature. Some yeasts present in a newly unfiltered VOO can remain viable and metabolically active during the storage of the oil, and according to their metabolic capacities, they can improve or worsen the physicochemical and sensory characteristics of VOO [19,20,49]. Enzymes produced by yeasts that are isolated from olives or olive oil include $\beta$-glucosidase, $\beta$-glucanase, phenoloxidase, peroxidase, lipase, esterase, and cellulase [19,21,23,44,49-51]. Moreover, $\beta$-glucosidase and esterase act on the bitter glucoside oleuropein and its derivative oleuropein aglycone, respectively, in olive oil [19]. The enzymatic hydrolysis of oleuropein reduces the bitter taste and improves the antioxidant and scavenging activities of VOO [19]. Other enzymes, such as lipase, phenoloxidase, and peroxidase, deteriorate the oil quality [52-55]. During the storage of VOO, some yeast species produce lipase (glycerol-ester-hydrolase, E.C. 3.1.1.3) that hydrolyzes the fatty acid acyl ester bonds of acylglycerols, consequently increasing the content of free fatty acids, which are very sensitive to autoxidation in the oil $[50,56]$. In detail, laboratory experiments with the inoculation of two oil-borne lipase positive yeast species, C. adriatica 1985 and C. parapsilosis 1984 yeast strains, and the lipase-negative Candida boidinii 1638 yeast strain, showed that the lipase-positive yeast strains increased the free fatty acid content and consequently reduced the quality during storage [21,56-58]. The lipase activity of yeasts is influenced by the ratio of the aqueous and organic phases, and it reaches the maximum value when the water added to the oil is $1 \%$ for C. adriatica and $0.25 \%$ for C. parapsilosis [21,50]. The polar phenol content of olive oil also influences the viability and lipolytic activity of the lipase-producing yeasts. Laboratory experiments conducted with olive oil with increasing contents of total polar phenols (89 mg, $159 \mathrm{mg}$ and $540 \mathrm{mg}$ CAE per $\mathrm{kg}$ ) determined the percentages of lipase-producing yeasts that could hydrolyze triacylglycerol $(100 \%, 67 \%$, and $11 \%$, respectively) [49]. During the storage of an unfiltered VOO, some yeast strains of the microbiota can influence the sensory characteristics of VOO, by reducing positive attributes such as fruitiness, bitterness, and pungency, or allowing the appearance of unpleasant sensory notes, which are classified into four groups: "fusty," "musty," "winey-vinegary," and "rancid", according to the current olive oil regulations [59]. Oleuropein and its aglycon form, among the polar phenols, are responsible for the bitterness of VOOs [60]. Oleacein and oleocanthal are responsible for the pungency of certain olive oils [61]. These positive attributes are not the criteria for an olive oil classification. Guerrini et al. [62] showed that sensory defects and specific volatile compounds (2-butanone, butyric acid, 2-heptanol, octanoic acid, and 1-octen-3-ol) were related to both yeast and mold concentrations in the freshly extracted and filtered oils. Inoculation trials conducted with the Leccino VOO demonstrated that during storage, some oil-borne yeast strains were responsible for the appearance of sensory defects. In detail, a micro-filtered Leccino VOO was inoculated with six oil-borne yeast strains belonging to C. adriatica, C. diddensiae, and N. wickerhamii. After four months 
of storage, sensory defects, such as "muddy-sediment", "rancid" or both, were found in olive oil treated with the C. adriatica 1933, N. wicherhamii 1885, and C. diddensiae 1912 and 1913 strains. In contrast, olive oil samples treated with the $C$. diddensiae 1918 and 1922 strains were defect-free and remained commercially classified as extra virgin [20]. Similarly, studies conducted by Guerrini et al. [23] with three oil-borne yeast strains belonging to $N$. wickerhamii, N. molendinolei, and Y. terventina demonstrated that after six months of storage, the volatile compound content was strongly influenced by the strain of the yeast inoculated. The olive oil samples treated with yeasts showed a higher concentration of compounds responsible for oil defects (trans 2-heptenal, 6-methyl-5-hepten-2-one, 2-octanone) and a lower concentration of $\mathrm{C} 6$ volatile carbonyl compounds responsible for positive oil attributes [23].

\section{Functional Properties of Oil-Borne Yeast Strains}

Currently, two yeasts, S. cerevisiae and Saccharomyces boulardii, which is a strain of the S. cerevisiae species, have been recognized as probiotics, and are available on the market. S. cerevisiae is frequently isolated from traditional fermented foods, and some strains have shown potential anti-ulcerogenic activity [63]. S. cerevisiae is used in the livestock sector, where animal feed is supplemented with the living cells of $S$. cerevisiae to improve growth, health, and immune response in hosts [64]. S. boulardii, isolated from the litchi fruit in Indochina by Henri Boulard in the 1920s, is used to treat diarrhea in adults and children infected with Clostridium difficile, diarrhea in the human immunodeficiency virus-infected patients, and acute and chronic diarrhea in children and adults [65-67]. Other yeast species found in non-oleic habitats include D. hansenii, Torulaspora delbruecki, Kluyveromyces marxianus, Kazachstania lodderae, C. norvegica, and Galactomyces reesii, and these species have shown tolerance while passing through the gastrointestinal tract and an ability to inhibit enteropathogens [68-70]. K. marxianus showed an anti-inflammatory activity against an inflammatory bowel disease [71]. Santona et al. [44] reported that among the 64 yeasts isolated from the Sardinian oleic ecosystems, 40 isolates were resistant to $\mathrm{pH} 2.5$ and 55 isolates to $1.5 \%$ bile salt. Unlike the S. boulardii and S. cerevisiae yeasts (which contain only saturated and mono-unsaturated fatty acids), the oil-borne yeast strains showed a higher concentration of polyunsaturated fatty acids (PUFAs) (Table 2) [24]. The high PUFA content in the yeast cells of olive oil, following their autolysis, may be useful in improving the essential fatty acid profile of olive oil, which has low contents of health- beneficial linolenic (omega-3) and linoleic (omega-6) acids [72]. In addition to a PUFA synthesis, other probiotic properties, such as the ability to tolerate unfavorable in vitro gastrointestinal conditions, have been demonstrated by yeasts isolated from VOOs. Some of our recent studies showed that unlike the yeasts suspended in the aqueous matrix, the yeasts suspended in oil survived well $(100 \%)$ during the gastrointestinal digestive tests that were simulated in vitro [24]. Based on these results, it may be hypothesized that a majority of yeasts, consumed daily through VOO, reach the intestinal tract. Another probiotic activity, shown by about $50 \%$ of the yeasts of the biotic fraction of VOO, is the ability to remove cholesterol in vitro. Among the tested yeast strains, the W. anomalus species demonstrated the best result (Table 3) [24]. Yeasts of the biotic fraction of VOO also showed antioxidant activity. Twenty-four yeast strains, belonging to eight species isolated from VOO, showed 2,2-diphenyl-1-picryl-hydrazyl (DPPH) free radical-scavenging activity, which was, in some cases, superior to that of the reference probiotic yeast strain S. boulardii. The highest antioxidant activity was observed in N. wickerhamii, exceeding the activity level of S. boulardii. Significantly lower values of antioxidant activity were recorded by C. adriatica, C. diddensiae, and Barnettozyma californica strains. All the oil-borne yeast strains studied in vitro showed DPPH free radical-scavenging activity in both physiological solution and olive oil. Tests performed with olive oil enriched with $W$. anomalus and S. boulardii yeast biomass showed a positive correlation between the yeast biomass and percentage of antioxidant activity [22]. 
Table 2. Average fatty acid composition of olive oil-borne yeast species, Saccharomyces boulardii and virgin olive oil (\%).

\begin{tabular}{|c|c|c|c|c|c|c|c|c|c|c|c|c|c|c|c|}
\hline \multirow[t]{2}{*}{ Free Fatty Acid } & \multicolumn{2}{|c|}{$\begin{array}{l}\text { Candida } \\
\text { adriatica }\end{array}$} & \multicolumn{2}{|c|}{$\begin{array}{c}\text { Candida } \\
\text { diddensiae }\end{array}$} & \multicolumn{2}{|c|}{$\begin{array}{l}\text { Nakazawaea } \\
\text { molendinolei }\end{array}$} & \multicolumn{2}{|c|}{$\begin{array}{l}\text { Nakazawaea } \\
\text { wickerhamii }\end{array}$} & \multicolumn{2}{|c|}{$\begin{array}{l}\text { Wickerhamomyces } \\
\text { anomalus }\end{array}$} & \multicolumn{2}{|c|}{$\begin{array}{l}\text { Yamadazyma } \\
\text { terventina }\end{array}$} & \multicolumn{2}{|c|}{$\begin{array}{l}\text { Saccharomyces } \\
\text { boulardii }\end{array}$} & \multirow[t]{2}{*}{$\begin{array}{c}\text { Olive } \\
\text { oil }\end{array}$} \\
\hline & No. * & $\% * *$ & No. & $\%$ & No. & $\%$ & No. & $\%$ & No. & $\%$ & No. & $\%$ & No. & $\%$ & \\
\hline & 2 & & 2 & & 2 & & 1 & & 2 & & 2 & & 1 & & \\
\hline Myristic acid (C14:0) & & 1.02 & & 1.29 & & 0.31 & & 0.22 & & 0.33 & & 0.40 & & 0.89 & 0.01 \\
\hline Palmitic acid (C16:0) & & 14.83 & & 20.72 & & 13.35 & & 9.41 & & 18.38 & & 16.34 & & 16.15 & 12.25 \\
\hline Palmitoleic acid (16:1) & & 7.56 & & 7.81 & & 9.13 & & 9.52 & & 4.90 & & 8.05 & & 47.01 & 0.79 \\
\hline Heptadecanoic acid (C17:0) & & 0.36 & & 0.00 & & 0.64 & & 0.65 & & 0.29 & & 0.49 & & 0.00 & 0.04 \\
\hline Heptadecenoic acid (C17:1) & & 2.71 & & 0.98 & & 2.49 & & 4.05 & & 1.98 & & 2.48 & & 0.66 & 0.06 \\
\hline Stearic acid (C18:0) & & 2.70 & & 1.72 & & 1.41 & & 0.98 & & 2.46 & & 2.33 & & 5.82 & 2.61 \\
\hline Oleic acid (C18:1) & & 36.72 & & 26.91 & & 31.76 & & 32.96 & & 35.47 & & 37.66 & & 26.49 & 73.50 \\
\hline Linoleic acid (C18:2) & & 25.51 & & 27.91 & & 31.00 & & 37.31 & & 30.96 & & 25.90 & & 0.00 & 9.09 \\
\hline Arachic acid (C20:0) & & 0.09 & & 3.34 & & 3.24 & & 2.05 & & 1.83 & & 0.30 & & 0.00 & 0.41 \\
\hline Linolenic acid (C18:3) & & 5.08 & & 9.48 & & 5.97 & & 2.21 & & 3.69 & & 5.07 & & 0.00 & 0.67 \\
\hline Eicosenoic acid (C20:1) & & 0.12 & & 0.00 & & 0.00 & & 0.00 & & 0.00 & & 0.03 & & 0.00 & 0.40 \\
\hline Behenic acid (C22:0) & & 0.06 & & 0.00 & & 0.00 & & 0.13 & & 0.07 & & 0.10 & & 0.00 & 0.10 \\
\hline Lignoceric tR acid (C24:0) & & 2.83 & & 0.32 & & 0.27 & & 0.00 & & 0.20 & & 0.36 & & 2.76 & 0.04 \\
\hline Total $\%$ & & 99.59 & & 99.76 & & 99.57 & & 99.49 & & 99.58 & & 99.51 & & 99.78 & 99.96 \\
\hline SFA & & 21.89 & & 27.39 & & 19.22 & & 13.44 & & 23.51 & & 20.32 & & 25.62 & 15.72 \\
\hline MUFA & & 47.11 & & 35.70 & & 43.38 & & 46.53 & & 42.02 & & 48.22 & & 74.16 & 74.75 \\
\hline PUFA & & 30.59 & & 36.67 & & 36.97 & & 39.52 & & 34.05 & & 30.97 & & 0.00 & 9.76 \\
\hline
\end{tabular}

*, number of yeast strains tested; **, \% fatty acid composition; SFA, saturated fatty acid; MUFA, mono-unsaturated fatty acid; PUFA, polyunsaturated fatty acid. 
Table 3. Some in vitro health-related probiotic activities of certain yeast species isolated from olive oil.

\begin{tabular}{|c|c|c|c|c|c|c|c|}
\hline Yeast Species. & No. * & $\begin{array}{l}\text { Cholesterol } \\
\text { Removal (\%) }\end{array}$ & No. & $\begin{array}{l}\text { Antioxidant } \\
\text { Activity (\%) }\end{array}$ & No. & $\begin{array}{c}\text { Specific Activity } \\
\left(\mathrm{U} \mathrm{g}^{-1} \text { Yeast Biomass }\right)\end{array}$ & Reference \\
\hline $\begin{array}{l}\text { Barnettozyma } \\
\text { californica }\end{array}$ & 0 & ND & 3 & 34.17 & 3 & 4.44 & [22] \\
\hline $\begin{array}{l}\text { Candida } \\
\text { adriatica }\end{array}$ & 2 & 14.97 & 6 & 47.00 & 6 & 6.27 & {$[22,24]$} \\
\hline $\begin{array}{l}\text { Candida } \\
\text { diddensiae }\end{array}$ & 2 & 14.20 & 4 & 36.50 & 4 & 4.77 & {$[22,24]$} \\
\hline $\begin{array}{l}\text { Nakazawaea } \\
\text { molendinolei }\end{array}$ & 2 & 44.45 & 3 & 59.50 & 3 & 8.06 & {$[22,24]$} \\
\hline $\begin{array}{l}\text { Nakazawaea } \\
\text { wickerhamii }\end{array}$ & 1 & 39.60 & 1 & 83.50 & 1 & 11.48 & {$[22,24]$} \\
\hline $\begin{array}{c}\text { Ogataea } \\
\text { histrianica }\end{array}$ & 0 & ND & 1 & 47.00 & 1 & 6.27 & [22] \\
\hline $\begin{array}{l}\text { Yamadazyma } \\
\text { terventina }\end{array}$ & 2 & 21.45 & 4 & 52.13 & 4 & 7.00 & {$[22,24]$} \\
\hline $\begin{array}{l}\text { Wickerhamomyces } \\
\text { anomalus }\end{array}$ & 2 & 60.52 & 2 & 50.00 & 2 & 6.74 & {$[22,24]$} \\
\hline $\begin{array}{l}\text { Saccharomyces } \\
\text { boulardii }^{* *}\end{array}$ & 1 & 35.38 & 1 & 70.00 & 1 & 9.55 & {$[22,24]$} \\
\hline
\end{tabular}

\section{Development of a Potentially Functional Olive Oil}

The daily intake of the bioactive abiotic endogenous fraction of VOOs, including phenols, depends on genetic, agronomic, and technological factors [73-77]. A wide range of VOOs, containing different amounts of total phenols and having different phenolic compositions, can be found on the market [78]. Different strategies have been proposed to optimize the daily intake of the bioactive abiotic endogenous fraction of VOOs. A strategy to optimize the daily intake of phenolic compounds in the habitual diet is to produce an enriched VOO with well-known bioactive phenols [79-83]. Different sources of natural bioactive ingredients, such as raw materials derived from the same olive tree (mainly leaves or residual olive pomace) obtained after the mechanical extraction of the oil, have been proposed to enrich oils. Other studies used plants and vegetables, mainly herbs and spices [84]. Studies on the enrichment of olive oil, with some components of the VOO biotic fraction, such as yeasts, continue to be rare. So far, research has shown that the biotechnological use of some yeast strains isolated from olive oil has provided scope for further studies. S. boulardii, a commercially available probiotic yeast, does not survive for a long time in olive oil [22]. Among the studied oil-borne yeast strains, the W. anomalus 2032 yeast strain, which has been characterized by the best performance in removing cholesterol in vitro and good antioxidant activity, survived in oil rich in polar phenols [22].

\section{Conclusions}

The biotic fraction of VOO mainly consists of yeasts. To date, approximately twenty-four yeast species have been identified in different types of olive oil, and seven of these species have been classified as new species. The activity of some yeasts of the VOO biotic fraction improves the sensory characteristics of the oil, through the production of $\beta$-glucosidase and esterase. Both enzymes act on phenolic compounds that are responsible for the bitter taste of the product. However, yeast can also worsen the quality of the product by allowing the appearance of defects, oxidation of polar phenols, and triacylglycerol hydrolysis. Interesting probiotic activities have been demonstrated in vitro by oil-borne yeast species. These activities are associated with a high PUFA content, the ability to remove cholesterol, free radical-scavenging activity, and the ability to colonize in the intestinal tract by overcoming the gastro-pancreatic barrier. The probiotic activity of oil-borne yeast strains may be of importance because VOO enrichment with these yeasts improves the health benefits of the product. 
Author Contributions: Each author contributed to the research and publication of this study in different ways, including conceptualization, B.A.Z. and G.C.; writing-original draft, B.A.Z. and G.C.; writing-review and editing, B.A.Z. and G.C.; supervision, G.C.; and funding acquisition, B.A.Z. and G.C. All authors have read and agreed to the published version of the manuscript.

Funding: This research was partially funded by the "Bando Industria Sostenibile, PON I\&C, 2014-2020, D.M. $1^{\circ}$ Giugno 2016" Ministry of Economic Development.

Acknowledgments: The authors express their thanks to Mrs. Giulia Venditti for her precious technical support.

Conflicts of Interest: The authors declare that they have no conflicts of interest.

\section{References}

1. Casado-Díaz, A.; Túnez-Fiñana, I.; Mata-Granados, J.M.; Ruiz-Méndez, M.V.; Dorado, G.; Romero-Sánchez, M.C.; Navarro-Valverde, C.; Quesada-Gómez, J.M. Serum from postmenopausal women treated with a by-product of olive-oil extraction process stimulates osteoblastogenesis and inhibits adipogenesis in human mesenchymal stem-cells (MSC). Exp. Gerontol. 2017, 90, 71-78. [CrossRef] [PubMed]

2. Masana, M.F.; Koyanagi, A.; Haro, J.M.; Tyrovolas, S. n-3 Fatty acids, Mediterranean diet and cognitive function in normal aging: A systematic review. Exp. Gerontol. 2017, 91, 39-50. [CrossRef] [PubMed]

3. Koidis, A.; Triantafillou, E.; Boskou, D. Endogenous microflora in turbid virgin olive oils and the physicochemical characteristics of these oils. Eur. J. Lipid Sci. Technol. 2008, 110, 164-171. [CrossRef]

4. Breschi, C.; Guerrini, L.; Domizio, P.; Ferraro, G.; Calamai, L.; Canuti, V.; Masella, P.; Parenti, A.; Fratini, A.; Fia, G.; et al. Physical, Chemical, and Biological Characterization of Veiled Extra Virgin Olive Oil Turbidity for Degradation Risk Assessment. Eur. J. Lipid Sci. Technol. 2019, 121, 1900195. [CrossRef]

5. Koidis, A.; Boskou, D. The contents of proteins and phospholipids in cloudy (veiled) virgin olive oils. Eur. J. Lipid Sci. Technol. 2006, 108, 323-328. [CrossRef]

6. Lozano-Sánchez, J.; Cerretani, L.; Bendini, A.; Segura-Carretero, A.; Fernández-Gutiérrez, A. Filtration process of extra virgin olive oil: effect on minor components, oxidative stability and sensorial and physicochemical characteristics. Trends Food Sci. Technol. 2010, 21, 201-211. [CrossRef]

7. Brenes, M.; García, A.; García, P.; Garrido, J. Acid hydrolysis of secoiridoid aglycons during storage of virgin olive oil. J. Agric. Food Chem. 2001, 49, 5609-5614. [CrossRef]

8. Fregapane, G.; Lavelli, V.; León, S.; Kapuralin, J.; Salvador, M.D. Effect of filtration on virgin olive oil stability during storage. Eur. J. Lipid Sci. Technol. 2006, 108, 134-142. [CrossRef]

9. Servili, M.; Montedoro, G.F. Contribution of phenolic compounds to virgin olive oil quality. Eur. J. Lipid Sci. Technol. 2002, 104, 602-613. [CrossRef]

10. Servili, M.; Selvaggini, R.; Esposto, S.; Taticchi, A.; Montedoro, G.F.; Morozzi, G. Health and sensory properties of virgin olive oil hydrophilic phenols: agronomic and technological aspects of production that affect their occurrence in the oil. J. Chromatogr. A 2004, 1054, 113-127. [CrossRef]

11. Franconi, R.; Coinu, R.; Carta, S.; Urgeghe, P.P.; Ieri, F.; Mulinacci, N.; Romani, A. Antioxidant effect of two virgin olive oils depends on the concentration and composition of minor polar compounds. J. Agric. Food Chem. 2006, 54, 3121-3125. [CrossRef] [PubMed]

12. Han, J.; Talorete, T.P.N.; Yamada, P.; Isoda, H. Antiproliferative and apoptotic effects of oleuropein and hydroxytyrosol on human breast cancer MCF-7 cells. Cytotechnology 2009, 59, 45-53. [CrossRef]

13. Omar, S.H. Oleuropein in olive and its pharmacological effects. Sci. Pharmac. 2010, 78, 133-154. [CrossRef] [PubMed]

14. Lucas, L.; Russell, A.; Keast, R. Molecular mechanisms of inflammation. Anti-inflammatory benefits of virgin olive oil and the phenolic compound oleocanthal. Curr. Pharm. Des. 2011, 17, 754-768. [CrossRef] [PubMed]

15. Warleta, F.; Quesada, C.S.; Campos, M.; Allouche, Y.; Beltrán, G.; Gaforio, J.J. Hydroxytyrosol protects against oxidation DNA damage in human breast cells. Nutrients 2011, 3, 839-857. [CrossRef]

16. Justino, C.I.L.; Pereira, R.; Freitas, A.C.; Rocha-Santos, T.A.P.; Panteleitchouk, T.S.L.; Duarte, A.C. Olive oil mill wasterwaters before and after treatment: a critical review from the ecotoxicologica point of view. Ecotoxicology 2012, 21, 615-619. [CrossRef]

17. Taghvaei, M.; Jafari, S.M. Application and stability of natural antioxidants in edible oils in order to substitute synthetic additives. J. Food Sci. Technol. 2015, 52, 1272-1282. [CrossRef] 
18. Gharby, S.; Harhar, H.; Mamouni, R.; Matthäus, B.; Addi, E.H.A.; Charrouf, Z. Chemical characterization and kinetic parameter determination under Rancimat test conditions of four monovarietal virgin olive oil grown in Morocco. Oilseeds Fats Crop. Lipids 2016, 23, A401. [CrossRef]

19. Ciafardini, G.; Zullo, B.A. Microbiological activity in stored olive oil. Int. J. Food Microbiol. 2002, 75, 111-118. [CrossRef]

20. Zullo, B.A.; Cioccia, G.; Ciafardini, G. Effects of some oil-born yeasts on the sensory characteristics of Italian virgin olive oil during its storage. Food Microbiol. 2013, 36, 70-78. [CrossRef]

21. Ciafardini, G.; Zullo, B.A. Virgin olive oil yeasts: A review. Food Microbiol. 2018, 70, 245-253. [CrossRef] [PubMed]

22. Ciafardini, G.; Zullo, B.A. In vitro potential antioxidant activity of indigenous yeasts isolated from virgin olive oil. J. Appl. Microbiol. 2020, 128, 853-861. [CrossRef] [PubMed]

23. Guerrini, S.; Mari, E.; Barbato, D.; Granchi, L. Extra virgin olive oil quality as affected by yeast species occurring in the extraction process. Foods 2019, 8, 457. [CrossRef] [PubMed]

24. Zullo, B.A.; Ciafardini, G. Evaluation of physiological properties of yeast strains isolated from olive oil and their in vitro probiotic trait. Food Microbiol. 2019, 78, 179-187. [CrossRef] [PubMed]

25. Mari, E.; Guerrini, S.; Granchi, L.; Vincenzini, M. Enumeration and rapid identification of yeasts during extraction process of extra virgin olive oil in Tuscany. World J. Microbiol. Biotechnol. 2016, 32, 93-103. [CrossRef] [PubMed]

26. Ciafardini, G.; Cioccia, G.; Zullo, B.A. Taggiasca extra virgin olive oil colonization by yeasts during the extraction process. Food Microbiol. 2017, 62, 58-61. [CrossRef]

27. Zullo, B.A.; Maiuro, L.; Ciafardini, G. Survival of Coliform Bacteria in Virgin Olive Oil. BioMed Res. Int. 2018, 2018, 8490614. [CrossRef]

28. Zullo, B.A.; Ciafardini, G. Lipolytic yeasts distribution in commercial extra virgin olive oil. Food Microbiol. 2008, 25, 970-977. [CrossRef]

29. Zullo, B.A.; Cioccia, G.; Ciafardini, G. Distribution of dimorphic yeast species in commercial extra virgin olive oil. Food Microbiol. 2010, 27, 1035-1042. [CrossRef]

30. Zullo, B.A.; Ciafardini, G. Changes in physicochemical and microbiological parameters of short and long-lived veiled (cloudy) virgin olive oil upon storage in the dark. Eur. J. Lipid Sci. Technol. 2018, 120, 1700309. [CrossRef]

31. Ciafardini, G.; Cioccia, G.; Zullo, B.A. Survival of Candida parapsilosis yeast in olive oil. Ann. Microbiol. 2013, 63, 1645-1648. [CrossRef]

32. Guerrini, L.; Zanoni, B.; Breschi, C.; Angeloni, G.; Masella, P.; Calamai, L.; Parenti, A. Understanding olive oil stability using filtration and high hydrostatic pressure. Molecules 2020, 25, 420. [CrossRef] [PubMed]

33. Kiritsakis, A.; Nanos, G.D.; Polymenopulos, Z.; Thomai, T.; Sfakiotakis, E.M. Effect of fruit storage conditions on olive oil quality. J. Am. Oil Chem. Soc. 1998, 75, 721-724. [CrossRef]

34. Zullo, B.A.; Ciafardini, G. Differential microbial composition of monovarietal and blended extra virgin olive oils determines oil quality during storage. Microorganisms 2020, 8, 402. [CrossRef]

35. Spencer, J.; Spencer, D. Ecology: Where Yeasts Live, in Yeasts in Natural and Artificial Habitats; Spencer, J., Spencer, D., Eds.; Springer: Berlin/Heidelberg, Germany, 1997; pp. 33-58.

36. Péter, G.; Dlauchy, D.; Tóbiás, A.; Fülöp, L.; Podgoršek, M.; Čadež, N. Brettanomyces acidodurans sp. nov., a new acetic acid producing yeast species from olive oil. Antonie van Leeuwenhoek 2017. [CrossRef]

37. Kurtzman, C.P.; Fell, J.W.; Boekhout, T. The Yeasts: A Taxonomic Study; Elsevier Science: Burlington, VM, USA, 2011.

38. Čadež, N.; Raspor, P.; Turchetti, B.; Cardinali, G.; Ciafardini, G.; Veneziani, G.; Péter, G. Candida adriatica sp. nov. and Candida molendinolei sp. nov., two yeast species isolated from olive oil and its by-products. Int. J. Syst. Evol. Microbiol. 2012, 62, 2296-2302. [CrossRef]

39. Čadež, N.; Dlauchy, D.; Raspor, P.; Péter, G. Ogataea kolombanensis sp. nov., Ogataea histrianica sp. nov. and Ogataea deakii sp. nov., three novel yeast species from plant sources. Int. J. Syst. Evol. Microbiol. 2013, 63, 3115-3123. [CrossRef]

40. Ciafardini, G.; Zullo, B.A.; Antonielli, L.; Corte, L.; Roscini, L.; Cardinali, G. Yamadazyma terventina sp. nov., a yeast species of the Yamadazyma clade from Italian olive oils. Int. J. Syst. Evol. Microbiol. 2013, 63, 372-376. [CrossRef] 
41. Čadež, N.; Dlauchy, D.; Tóbiás, A.; Péter, G. Kuraishia mediterranea sp. nov., a methanol-assimilating yeast species from olive oil and its sediment. Int. J. Syst. Evol. Microbiol. 2017, 67, 4846-4850. [CrossRef]

42. Buescher, R.W.; Burgin, C. Diffusion plate assay for measurement of polygalacturonase activities in pickle brine. J. Food Biochem. 1992, 16, 59-68. [CrossRef]

43. Golomb, B.L.; Morales, V.; Jung, A.; Yau, B.; Boundy-Mills, K.L.; Marco, M.L. Effects of pectinolytic yeast on the microbial composition and spoilage of olive fermentations. Food Microbiol. 2013, 33, 97-106. [CrossRef] [PubMed]

44. Santona, M.; Sanna, M.L.; Multineddu, C.; Fancello, F.; de la Fuente, S.A.; Dettori, S.; Zara, S. Microbial biodiversity of Sardinian oleic ecosystems. Food Microbiol. 2018, 70, 65-75. [CrossRef] [PubMed]

45. Pizzolante, G.; Durante, M.; Rizzo, D.; Di Salvo, M.; Tredici, S.M.; Tufariello, M.; De Paolis, A.; Talá, A.; Mita, G.; Alifano, P.; et al. Characterization of two Pantoea strains isolated from extra-virgin olive oil. AMB Express 2018, 8, 113. [CrossRef] [PubMed]

46. Fancello, F.; Multineddu, C.; Santona, M.; Deiana, P.; Zara, G.; Mannazzu, I.; Budroni, M.; Dettori, S.; Zara, S. Bacterial biodiversity of extra virgin olive oils and their potential biotechnological exploitation. Microorganisms 2020, 8, 97. [CrossRef]

47. Ciafardini, G.; Zullo, B.A. Survival of microorganisms in extra virgin olive oil during storage. Food Microbiol. 2002, 19, 105-109. [CrossRef]

48. Vichi, S.; Romero, A.; Tous, J.; Caixach, J. The activity of healthy olive microbiota during virgin olive oil extraction influences oil chemical composition. J. Agric. Food Chem. 2011, 59, 4705-4714. [CrossRef]

49. Ciafardini, G.; Zullo, B.A. Effect of lipolytic activity of Candida adriatica, Candida diddensiae and Yamadazyma terventina on the acidity of extra-virgin olive oil with different polyphenol and water content. Food Microbiol. 2015, 47, 12-20. [CrossRef]

50. Ciafardini, G.; Zullo, B.A.; Iride, A. Lipase production by yeasts from extra virgin olive oil. Food Microbiol. 2006, 23, 60-67. [CrossRef]

51. Romo-Sanchez, S.; Alves-Baffi, M.; Arévalo-Villena, M.; Úbeda-Iranzo, J.; Briones-Pérez, A. Yeast biodiversity from oleic ecosystem: study of their biotechnological properties. Food Microbiol. 2010, 27, 487-492. [CrossRef]

52. Zullo, B.A.; Pachioli, S.; Ciafardini, G. Reducing the bitter taste of virgin olive oil Don Carlo by microbial and vegetable enzymes linked to the colloidal fraction. Colloids Interfaces 2020, 4, 11. [CrossRef]

53. Migliorini, M.; Cecchi, L.; Cherubini, C.; Trapani, S.; Cini, E.; Zanoni, B. Understanding degradation of phenolic compounds during olive oil processing by inhibitor addition. Eur. J. Lipid Sci. Technol. 2012, 114, 942-950. [CrossRef]

54. Campestre, C.; Angelini, G.; Gasbarri, C.; Angerosa, F. The compounds responsible for the sensory profile in monovarietal virgin olive oils. Molecules 2017, 22, 1833. [CrossRef] [PubMed]

55. Palla, M.; Digiacomo, M.; Cristani, C.; Bertini, S.; Giovannetti, M.; Macchia, M.; Manera, C.; Agnolucci, M. Composition of health-promoting phenolic compounds in two extra virgin olive oils and diversity of associated yeasts. J. Food Compos. Anal. 2018, 74, 27-33. [CrossRef]

56. Ciafardini, G.; Zullo, B.A.; Cioccia, G.; Iride, A. Lipolytic activity of Williopsis californica and Saccharomyces cerevisiae in extra virgin olive oil. Int. J. Food Microbiol. 2006, 107, 27-32. [CrossRef]

57. Brockerhoff, H.; Jensen, R.G. Lipase. Lipolytic Enzymes; Academic Press: New York, NY, USA, 1974; pp. $25-175$.

58. Schith, R.D.; Verger, R. Lipases: interfacial enzymes with attractive applications. Angew. Chem. Int. Ed. 1978, 37, 1608-1633.

59. Commission Implementing Regulation (EU) No. 1348/2913. OJEU. L338:3; Publications Office of the European Union: Luxembourg, 2013.

60. Caponio, F.; Gomes, T.; Pasqualone, A. Phenolic compounds in virgin olive oils: influence of the degree of olive ripeness on organoleptic characteristics and shelf-life. Eur. Food Res. Technol. 2001, 212, 329-333. [CrossRef]

61. Andrewes, P.; Busch, J.L.H.C.; De Joode, T.; Groenewegen, A.; Alexandre, H. Sensory properties of virgin olive oil polyphenols: Identification of deacetoxyligstroside aglycon as a key contributor to pungency. J. Agric. Food Chem. 2003, 51, 1415-1420. [CrossRef]

62. Guerrini, S.; Mari, E.; Migliorini, M.; Cherubini, C.; Trapani, S.; Zanoni, B.; Vincenzini, M. Investigation on microbiology of olive oil extraction process. Ital. J. Food Sci. 2015, 27, 237-247. 
63. Banik, A.; Mondal, J.; Rakshit, S.; Ghosh, K.; Sha, S.P.; Halder, S.K.; Ghosh, C.; Mondal, K.C. Amelioration of cold-induced gastric injury by a yeast probiotic isolated from traditional fermented foods. J. Funct. Foods 2019, 59, 164-173. [CrossRef]

64. Shen, Y.B.; Piao, X.S.; Kim, S.W.; Wang, L.; Liu, P.; Yoon, I.; Zhen, Y.G. Effects of yeast culture supplementation on growth performance, intestinal health, and immune response of nursey pigs. J. Anim. Sci. 2009, 87, 2614-2624. [CrossRef]

65. McFarland, L.V.; Bernasconi, P. Saccharomyces bourlardii: a Review of an innovative biotherapeutic agent. Microb. Ecol. Health Dis. 1993, 6, 157-171.

66. Ouwehand, A.C.; Salminen, S.; Isolauri, E. Probiotics: an overview of beneficial effects. Antonie Leeuwenhoek 2002, 82, 279-289. [CrossRef] [PubMed]

67. Czerucka, D.; Piche, T.; Rampal, P. Review article: yeast as probiotics-Saccharomyces boulardii. Aliment. Pharmacol. Ther. 2007, 26, 767-778. [CrossRef] [PubMed]

68. Psani, M.; Kotzekidou, P. Technologic characteristics of yeast strains and their potential as starters adjuncts in Greel-style black olive fermentation. World J. Microbiol. Biotechnol. 2006, 22, 1329-1336. [CrossRef]

69. Kourelis, A.; Kotzamanidis, C.; Litopoulou-Tzanetaki, E.; Scouras, Z.G.; Tzanetakis, N.; Yiangou, M. Preliminary probiotic selection of dairy and human yeast strains. J. Biol. Res. (Thessalon.) 2010, 13, 93-104.

70. Oliveira, T.; Ramalhosa, E.; Nunes, L.; Pereira, J.A.; Colla, E.; Pereira, E.L. Probiotic potential of indigenous yeasts isolated during the fermentation of table olives from Northeast of Portugal. Innovat. Food Sci. Emerg. Technol. 2017, 44, 167-172. [CrossRef]

71. Chopade, L.R.; Paradeshi, J.S.; Amrutkar, K.P.; Chaudhari, B.L. Finding out potent probiotic cultures from ayurvedic formulation Takrarishta through in vitro-probiotic characterization and principal component analysis. LWT 2019, 100, 205-212. [CrossRef]

72. Pauls, S.D.; Rodway, L.A.; Winter, T.; Taylor, C.G.; Zahradka, P.; Aukema, H.M. Anti-inflammatory effects of $\alpha$-linolenic acid in M1-like macrophages are associated with enhanced production of oxylipins from $\alpha$-linolenic and linoleic acid. J. Nutr. Biochem. 2018, 57, 121-129. [CrossRef]

73. Gómez-Rico, A.; Fregapane, G.; Salvador, M.D. Effect of cultivar and ripening on minor components in Spanish olive fruits and their corresponding virgin olive oils. Food Res. Int. 2008, 41, 433-440. [CrossRef]

74. Frankel, E.; Bakhouche, A.; Lozano-Sánchez, J.; Segura-Carretero, A.; Fernández-Gutiérrez, A. Literature review on production process to obtain extra virgin olive oil enriched in bioactive compounds. Potential use of by-product as alternative sources of polyphenols. J. Agric. Food Chem. 2013, 61, 5179-5188. [CrossRef]

75. Fregapane, G.; Salvador, M.D. Production of superior quality extra virgin olive oil modulating the content and profile of its minor components. Food Res. Int. 2013, 54, 1907-1914. [CrossRef]

76. Ciafardini, G.; Zullo, B.A. Improvement of commercial olive oil quality through an evaluation of the polyphenol content of the oily fraction of the olive fruit during its period of maturation. J. Food Process Technol. 2014, 5, 397.

77. Zullo, B.A.; Di Stefano, M.G.; Cioccia, G.; Ciafardini, G. Evaluation of polyphenol decay in the oily fraction of olive fruit during storage using a mild sample handling method. Eur. J. Lipid Sci. Technol. 2014, 116, 160-168. [CrossRef]

78. Segade, M.; Bermejo, R.; Silva, A.; Paiva-Martins, F.; Gil-Longo, J.; Campos-Toimil, M. Involvement of endothelium in the vasorelaxant effects of 3,4-DHPEA and 3,4-DHPEA-EDA, two major functional bioactives in olive oil. J. Funct. Foods 2016, 23, 637-646. [CrossRef]

79. Suárez, M.; Romero, M.P.; Motilva, M.J. Development of a phenol enriched olive oil with phenolic compounds from olive cake. J. Agric. Food Chem. 2010, 58, 10396-10403. [CrossRef] [PubMed]

80. Achat, S.; Tomao, V.; Madani, K.; Chibane, M.; Elmaataoui, M.; Dangles, O.; Chemad, F. Direct enrichment of olive oil in oleuropein by ultrasound-assisted maceration at laboratory and pilot plant scale. Ultrason. Sonochem. 2012, 19, 777-786. [CrossRef]

81. Rubió, L.; Motilva, M.J.; Macià, A.; Ramo, T.; Romero, M.P. Development of a phenol-enriched olive oil with both its own phenolic compounds and complementary phenols from thyme. J. Agric. Food Chem. 2012, 60, 3105-3112. [CrossRef]

82. Garrido, M.; González-Flores, D.; Marchena, A.M.; Prior, E.; García-Parra, J.; Barriga, C.; Rodríguez-Moratinos, A.B. A lycopene-enriched virgin olive enhances antioxidant status in humans. J. Sci. Food Agric. 2013, 93, 1820-1826. [CrossRef] 
83. Fernández-Castillejo, S.; Valls, R.M.; Castañer, O.; Rubió, L.; Catalán, Ú.; Pedret, A.; Macià, A.; Sampson, M.L.; Covas, M.I.; Fitó, M.; et al. Polyphenol rich olive oils improve lipoprotein particle atherogenic ratios and subclasses profile: A randomized, crossover, controlled trial. Mol. Nutr. Food Res. 2016, 60, 1544-1554. [CrossRef]

84. Reboredo-Rodriguez, P.; Figueiredo-González, M.; González-Barreiro, C.; Simal-Gándara, J.; Salvador, M.D.; Cancho-Grande, B.; Fregapane, G. State of the art on functional virgin olive oils enriched with bioactive compounds and their properties. Int. J. Mol. Sci. 2017, 18, 668. [CrossRef]

(C) 2020 by the authors. Licensee MDPI, Basel, Switzerland. This article is an open access article distributed under the terms and conditions of the Creative Commons Attribution (CC BY) license (http://creativecommons.org/licenses/by/4.0/). 